\title{
25 YEARS AFTER TRANSFORMATION: CHANGES IN SPATIAL DISTRIBUTION OF PRODUCTION ACTIVITIES IN THE CASE STUDY OF WROCLAW
}

\author{
Jan Barski, Jacek Barski \\ Faculty of Architecture, Department of Spatial Planning \\ Wroclaw University of Technology \\ Bolesława Prusa 53-55, 50-317 Wrocław: Poland \\ jan.barski@pwr.edu.pl, jacek.barski@pwr.edu.pl
}

\begin{abstract}
In the post-industrial, free-market economy, the ability of spatial planning to truly influence the location choices of business owners is limited, while the vast majority of means of production are in non-public hands. On top of that, coordinating spatial policies and decisions between administrative entities is a major challenge in numerous places in Europe. The aim of the paper is to assess the case of a medium-sized European city (Wroclaw, Poland) and its spatial management complication which has observable consequences for the spatial structure and economic functioning of the city. The paper examines the situation through the lens of production and manufacturing activities (with a cautious approach to the term 'industry'). The case is analysed in two inseparable ways: spatial and economic; in parallel, the discussion is developed on the issue of the interconnection of policy-making in the metropolitan area (the city "vs." its surrounding rural communes). The paper reviews the changes in employment in the subsequent sectors of the metropolitan area in within 25 years since the political transformation of Poland while keeping an eye on the physical and spatial changes of the aforementioned metropolitan area. The secondary output of the paper is outlining the suburbanisation processes of large Polish cities, however as seen not from the most frequently presented perspectives (such as housing or transportation) but from a more economy- and spatial responsibility-focused one.
\end{abstract}

Keywords: industry, suburbanisation, spatial distribution of activities.

\section{Introduction}

Poland, along with all post-communist countries of Central Europe, has been subject to major changes in its spatial structure, its functioning and growth in the period of the twenty-five years which had passed since the political transformation. Due to the totality of change - the switch from planned economy to free market and from façade citizen rights to direct democracy - the transition in space management can hardly be called gradual or well-groomed. This paper examines a very narrow fragment of the otherwise massive topic as it focuses on only a minute portion of the territory of Poland - Wroclaw, the country's fourth largest city and its agglomeration - and just one of many economic phenomena exemplified in spatial phenomena - the industry sector or, in more precise words, production activities (the terminology challenge is discussed briefly later in the paper). This 
paper is a stub of research conducted at the Department of Spatial Planning, Faculty of Architecture, Wroclaw University of Technology, addressing the issue of spatial behaviour of production activities in middle-sized cities of Central Europe and will include three more cities similar in size and history to Wroclaw: two Polish ones (Poznan and Szczecin), and an Eastern German one (Dresden).

The opening part of this paper is an overview of topics constituting the background for the phenomena discussed within the text. The middle part of the article summarises briefly the chaotic setup resulting from the current state of affairs. The main part of the paper assesses the mechanics of industrial suburbanisation both in general terms and in particular perspective of the city of Wrocław. The paper ends with conclusions.

\section{Background}

In order for an outlook of the very specific case which is the focus of this paper to be understandable better, it is worth to paint a picture of underlying phenomena. This includes observations of extremely general nature as well as the ones of more specific and local character.

The fundamentally good and desired value of the ability of societies and communities to make their own decisions collectively through their representatives, instead of ones made in an arbitrary way by any type of officials, has a trade-off side. The existence of private property means that the citizens are free to fully own material goods, among which land, and therefore space, is a prominent feature. In fact, "elements of space", as buildings and plots of open land may be dubbed, have been considered throughout the history of human civilisation as one of the topmost valuable and tradable goods, in the realm of material ones rivalled perhaps only by food. The free real estate market means that individuals are able and free to make their own, individual decisions concerning the land and buildings they own, which in multitude of owners and decisions builds up to a great challenge in coordinating the transformations of the common space - a difficulty significantly reduced by limitations in private property and commonality of decisions: an obvious feature of any semi-free political system.

A surprisingly unknown realisation is that space, in all scales considered together, is the arena for literally all that happens and can be named - outside of the human mind. This underlies why the construction of laws and regulations concerning space is an inexplicably complex task: legal provisions dealing with space in fact indirectly address most facets of life. All over the world, spatial regulations are far from perfect, especially if their functioning is relatively young and the ability of the public to influence it hardly has an established nature, which is the case in Poland.

Among numerous shortcomings of the Polish spatial law, the following can be named in an attempt to clarify the setting of the spatial changes of the last 25 years:

- soft and imperfectly consistent strategic documents:

- a regularly-updated national spatial development plan is in force, however its power and efficiency in executing spatial transformations are limited;

- regional spatial strategies are well-thought-through, but similarly may be accused of containing provisions which are soft and difficult to apply in conformity with the original intent or scope;

- at the lowest administrative level there is a harmful gap in the power of the general planning document established by every commune and updated every several years (the 
so-called Study of conditions and directions of spatial development of a commune) and the specific, smaller-area local land use plans;

- all levels of planning have been marked by unimpressive public participation standards. However, a new Act on spatial planning is being currently drafted and is to include public participation mechanisms inscribed in the planning processes incomparably more thoroughly. The Studies of conditions and directions..., independent of quality, do not carry executive or punitive power, and are in fact well-informed guidelines which local land use plans are supposed to follow (but not have to); the local plans are the only documents in the Polish planning system which have actual executive power. The difficulties, however, do not end here, as local plans:

a) do not cover $100 \%$ of the area of all communes (in other words, only a minority of communes is fully covered with local land use plans);

b) do not sum up to any regional or sub-regional larger picture;

c) may be changed or originally created in a way which suits short-term or particular goals of local politicians or external investors (and frequently that is the case, especially in less privileged areas).

This leads to perhaps the most natural explanation of decisions made by local authorities: the economic factors. It is clear that just a minuscule proportion of communes, and not even always, is able to afford choosing and picking its investors. In the vast majority of scenarios, communes race to attract investors and if they succeed, they largely conform to the investors' wishes and needs. This is to no surprise, taking the post-transformation reality of radical, rapid change and the need (or necessity) to secure the economic fundamentals first (such as jobs, tax base, territorial brand) into account and viewing the quality of space as a desirable, but undoubtedly secondary goal.

An additional argument could be made here concerning the psychology of the post-communist societies. It might be possible to defend a claim that due to being deprived of such seemingly natural privileges as private property, freedom to travel, move home, or change jobs for five decades, the citizens of these countries, in collective, are prone to compensate on the ability to consume. If such assumption is followed, then correlation can be made to striving for own material goods - therefore the preference for private cars over public transportation or for (often suburban) home ownership over (mostly in-city) apartment rental. This, globally, contributes more to urban sprawl phenomena than compact- or slow-city ideas.

Moreover, the reverse from the local scale - i.e. the global one - has come into play in the last two decades with a challenging effect. First of all, two sides of the economic landscape have opened colossally widely: competition and opportunity. The scope of what local authorities may think of achieving has broadened to an extent and that sometimes puts a serious strain on the communes' resourcefulness and imaginativeness. Meanwhile, very-open and very-free market makes everybody equally eligible for the investment sweepstakes, therefore pushing competition to new levels; this competition, naturally, brings both good results (such as creation of better conditions for investors, which leads to successful investment benefiting the whole regions) and bad ones (excessive lowering of the investment conditions or stepping away from other standards, thus hurting the regional employment market more than helping it). With all of this in mind, the communes of the region in question - Lower Silesia - weigh their strengths and weaknesses in their strategies and in negotiations with potential investors. In a generalised description, among strengths of Lower Silesian communes one could name the region's international and interregional location, relatively good transportation network and external transportation connections, relatively attractive workforce understood as a product of cost and qualification, and low salary requirements (for the Western-world standards). 
Among weaknesses, one could point to the frequently-reminded time limitation of the low-salary advantage (as it will stop being an advantage along with the gradual overall increase in wealth of the Polish society), and a relatively small internal market.

Finally, the general national policy in the realm of transportation needs to be commented on. In Poland, the whole post-transformation era has been marked by extensive efforts to develop vehicular traffic ${ }^{1}$, unparalleled in attempts to improve - or maintain, as they were operational in the socialist era - railways ${ }^{2}$ and inland navigation. Undoubtedly, the development and improvement of the road network in Poland, highlighted by the ever-expanding length of motorways, is more than significant for the country's economy and the quality of life; it does, however, benefit spatial behaviour - both residential and commercial - which favours perimeter locations over the downtown ones. The above general description is particularly true in the case of Lower Silesia, which had the luck of being equipped with a long, existing stretch of a pre-war German motorway (A4), which later was among the first ones to be extended further towards east and west; that was coupled with a significant decrease in the available regional railway connections and a decline in the capabilities of waterways. Most of the phenomena mentioned in this subchapter have been observed or anticipated by non-Polish scholars as well (e.g. Kunzmann \& Wegener 1991).

\section{Resulting situation}

The background described above bears consequences which strongly influence the challenges the Polish planning system faces. Primarily, territorial competition is born which, although fundamentally healthy, is easy to skew towards chaos. This type of competition naturally leads to territorial marketing - being a phenomenon significant enough to become a separate class taught to spatial planning students of Polish universities. Territorial competition and marketing accompanying it do not support the cause of territorial cooperation or cohesion. The higher the level of strategic spatial plan, the easier the cooperation to envisage and arrange; the more local the level in question is, the more neighbouring administrative entities are likely to fight each other instead of cooperating.

Clearly, the lack of truly executable coordination of spatial development results in chaos and conflicts - in transportation (city vs. its suburbs and agglomeration ${ }^{3}$ ), in taxation (the situation where a majority of residents of areas from outside the city limits the use of numerous services including these financed from the public [municipal] treasury in this city, while paying their taxes in the neighbouring commune they live in), in the quality of work and free time (time spent on commuting, increased difficulty in accessing recreation and culture), or image-wise (the arguable visual appeal of 1990s' and 2000s' suburban urbanisation, and the embarrassing reputation of an agglomeration which is stuck in traffic jams). To make things more challenging, all above is being said with no attention paid to whether the metropolis itself is working well or not.

\footnotetext{
1 The number of cars in Poland grew from 5.26 million in 1990 to 17.24 million in 2010. (Zdanowski 2012).

2 The number of passengers of the railway transportation per annum was at 1 billion in 1985, 0.79 billion in 1990, 0.36 billion in 2000 and 0.26 billion in 2010. The average citizen of Switzerland travels by train 43 times a year (European high); of the Czech Republic (also a post-communist country) 17.5 times; of Poland - 7 times (Zdanowski 2012).

3 In this paper, as well as in all discussions about the Polish urbanisation, the word "agglomeration" is used merely in its common and semantic sense, rather than in any specific way meaningful for spatial planning. Poland has no legislation which would establish any structure for major cities and their surrounding settlements. For this and other reasons, the local attempts to create agglomeration associations are only subject to their internal success or failure, with no potential support from external legal provisions or mechanisms.
} 


\section{Industry 4 and "industrial suburbanisation"}

In Poland, only between 2004 and 2010, the number of jobs in predominantly urban regions ${ }^{5}$ (to which the Wroclaw agglomeration belongs as one of several in Poland) increased by $20 \%$ (Adamczyk 2014). Although the direction of change - growth - is not surprising, its dynamics may be. This figure illustrates the fast urbanisation and strength of the largest settlements in the country. Between 1987 and 2007 , the employment rate in the industrial and construction sector decreased from $36.3 \%$ to $29.0 \%$ with a dip observed in the mid-term (25.2\% in 2001), after which it bounced back by a couple of percentage points. The figures for the year 2006 (29.6\%) placed Poland above the EU-27 average (25.0\%), however at exactly the same share in this sector as in Germany (Zajdel 2010). This can lead to the two main conclusions: 1 ) that the industry and construction sectors continue to provide for a lot of jobs despite the perceived crash resulting from the decomposition of obscure, heavy socialist-era industry; and 2) that the move towards the western-type economy relying strongly on so-called services and self-employment is fuelled largely by shift from traditional forms of economy, mostly from agriculture-related professions ${ }^{6}$. A relatively large proportion of industrial jobs is a topic for discussion from a few points of view, particularly in the strategic and economic aspect (the idea of reindustrialisation of Europe; the question of sustainability of industrial economic growth), and the aspects of ecology and image (the good reputation of "green" industries vs. conventionally poor reputation of industry in general). Throughout the 25 post-transformation years of Polish history, however, the number of available industrial jobs seems even insufficient for the economic needs of the country, keeping in mind the most dire unemployment phases $(20.0 \%$ in 2002$)$ and the current moderate unemployment rate (11.6\% for April 2015).

In the regional scale, research shows Wroclaw and Lower Silesia as being in an average-to-good situation concerning the industrial sector of the economy. Work efficiency research depicts the region as one of the leaders in the country (Rachwał 2010).

This couples with the region's convenient geographical location in attracting foreign and domestic investments. In a research focusing on innovation potential, Wroclaw was classified as type II: equipped with a well-developed R\&D base and poor industrial resources (Fig. 1); the referred research points at significant growth of the service sector in this type of cities (Siłka 2012).

Another reason might be found in the collapse of old, large-scale industries of the previous era and the rise of more modern industries, many of which have geographically settled outside the city limits. With the administrative constraints in mind, in a study of the number of foreign investments attracted by Polish cities between the transformation and 2012, Wroclaw ranks second in the country after Warsaw ${ }^{7}$ with 55 investments and experienced a $6.7 \%$ increase in that number between 2008 and 2012 (Głębocki 2013). Figures for all cities would be certainly higher, provided that the investments located in their vicinities are taken into account. In the case of Wroclaw the increase in the count could be significant [future works within this research will explore this topic]. Finally, studies on the economic base of major Polish cities point at Wroclaw as having a solid

\footnotetext{
4 The paper focuses on all production activities of the economy and postulates using the word "industry" in a broader (ironically, post-industrial) sense than its traditional, relatively pejorative one. Moreover, in the current technological and globalised era, the border between the industry and the service sectors is more blurry than ever.

5 As classified by Eurostat.

6 This share was still the highest in Europe in 2006, at $15.6 \%$.

7 However, the capital drew exponentially more investments than any other city - 509 - and more than the next 25 cities in the ranking combined. This, again, makes an imperfect count since the seats of multiple companies are located in the capital, which does not necessarily fully represent their geographical business focus.
} 
industrial workforce foundation with some surplus in this sector, despite noticeable industrial job market already in place (Sokołowski 2008; Przybyła \& Gonda-Soroczyńska 2013).

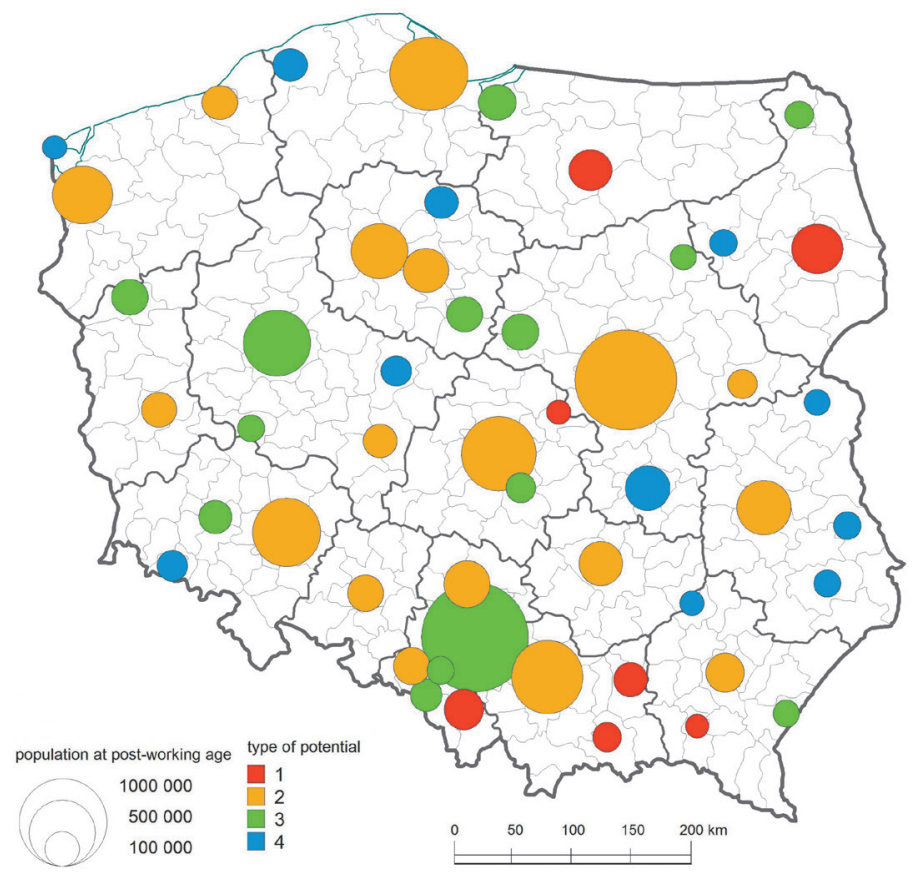

Figure 1. Classification of Polish cities according to innovation potential type (2008) Source: (Siłka 2012).

In order to shed some light on "industrial suburbanisation", as well as on the difficulties in conducting a cohesive agglomeration spatial policy, and in order to keep the particular focus on the city of Wroclaw, a number of explanations need to be provided. A look on production companies located in the downtown areas of cities may serve as a convenient starting point. Primarily, they are subject to their own technological regime, as well as to standards and regulations. When faced with a must to modernise, companies calculate whether it pays them better to invest in modernisation in their current location or in construction of new facilities in a new location. Frequently, the result favours the latter solution, especially since it additionally poses an opportunity to switch to modern, prospective technologies and hopefully make a technological leap. This scenario is more probable in particular in the case of space-consuming industries, which find perimeter locations more comfortable and affordable. The more modern and high-tech ones - which frequently means less materially productive ones - the greater need for smaller space and affordability to stay in more attractive, central locations. This is coupled with the aforementioned efforts of communes located in vicinity of large cities to attract investors, which by so far does not mean only the external ones; luring in a company from inside their own metropolis is just as good, if the final result is as desired.

Most (non-global) companies, even if they decide to move their seat, prefer to stay in their regions. That results for example from the already-established contact network or the well-known market. The move then takes them to suburban communes. The regional connotation remains, however, frequently connected with an office or a branch in the metropolis. Such a company needs 
to dispose of the property which it had occupied before the move, and faces the question for what use the property is suitable. Continuation of the industrial activity is unlikely, because then the original company might not have moved at all; therefore, such real estate undergoes a change according to the fashion of the time, transforming itself into petrol stations, residential estates, cheap or regular supermarkets, etc. The issues of deindustrialisation and company relocation have been present in European literature of various thematic areas in the last decades (Muller et al. 2005; Ciaramella \& Dettwiler 2011).

As far as the efforts to create and maintain a cohesive spatial plan for an agglomeration are concerned, a division line between the main city and its neighbours is clearly visible. The metropolis, naturally, cares for the best possible balance between the number of available jobs, number of available and affordable homes, transportation capabilities, cultural/entertainment offer, and multiple other factors. In consequence, the city tries to keep any production (industrial) company wanting to move away from it; if that fails, it tries to work towards a scenario in which the replacing business comes also from the industrial realm (or from a different but work-related one). This is caused by a number of reasons, but primarily due to the need of sustaining the jobs the leaving company vacates, and due to the resulting spatial conflicts (for instance, between a newly-introduced residential use and the pre-existing "unfriendly" uses, such as industry or a railway line). At this point, the aforementioned crucial difference in the power of the two documents - the Study of conditions... and the local land use plans - can be traced: municipalities have incomparably more influence on spatial turnover if they had managed to implement a local plan for an area before it underwent a change.

This entire spatial struggle described above is however being played out on the stage of single communes; no documents exist which would coordinate a larger number of them. As it has been said earlier, a national spatial plan and regional plans are implemented, however they mostly include the most serious public initiatives; agglomeration-scale postulates presented in them are either not executable or are too "soft" to stand the clash with the everyday practice. Even if there was a mechanism for creation of such documents existing, then a new tension would emerge: who would be supposed to draft them (what kind of body), and what would be the roles of the parties (especially of the metropolis) and the division of votes among them. The nature of this tension is clear: the administrative entities surrounding the metropolis would fight tooth and nail for a nonweighted split, and the metropolis would want the opposite.

In general, the difficulty in keeping industrial activity inside large cities is serious. In order to name a handful of particular Wroclaw cases, the following could be brought to attention:

- the massive former rail infrastructure repair facilities (ZNTK) in the north of the city have been long divided into numerous smaller businesses;

- the historic "Piast" brewery, partly preserved due to conservation protection, partially dismantled and partially unused, was supposed to be converted into an attractive loft apartment complexes, which was not executed;

- the so-called "burgher brewery", located in the eastern part of downtown, has been transformed into a cultural centre;

- the large former meat production facilities, in western part of the city centre, have been partially conserved as historical architecture and converted into a large shopping centre;

- the refractory materials production facilities, located in the westernmost district of the city, remain undeveloped until today; 
- the PaFaWag railway production plant pose a rather positive case - but largely due to the presence of local land use plans; from a major industrial facility, it has first turned into a rental area for all kinds of businesses, then (as a part of another market fashion) into a private university hub, to finally reach the stage of hosting technology parks and some smaller production companies.

The areas which the city has allocated for industry or production activities are also "frozen" to some extent under land uses, which may only be converted into something else in the future - such as allotment garden complexes. Moreover, it should be mentioned that with the acknowledgment of the existing trends and with the use of the available planning tools, many areas in Wroclaw have been secured for production activities. However, these located close to the border of the city will stay empty as long as the plots a couple of hundred metres away, outside the city limits, are simply cheaper to buy or rent.

\section{Conclusions. Future work}

A crucial notion needing attention in this discussion is that the challenge lies in the continuous nature of industrial activity. A developer who has completed a residential estate aims at selling the apartments; if this succeeds, the company moves on to another project. An industrial company, in turn, needs to have its operation safe for years, and therefore calculates differently than other businesses.

The described situation is similar in other post-communist countries, but the authors of this paper are unable to offer a comparison with proper scientific responsibility. The opened research will, as mentioned in the introduction, include a case from outside of Poland (Dresden, Germany). The next stages in the research will focus on hard statistical data (figures describing production activities in the selected cities), and on spatial representation of the changes of the last 25 years (mapping).

\section{References}

Adamczyk P., 2014. Przestrzenna koncentracja zatrudnienia w Polsce - wybrane aspekty teoretyczne i empiryczne [in:] Annals of agricultural economics and rural development, vol. 101(1), Warsaw: Polish Academy of Sciences.

Ciaramella A., Dettwiler P., 2011. A relocation model of European manufacturing firms. Cases from Italy and Sweden. Journal of Corp Real Estate, vol. 13(4), pp. 233-246.

Głębocki K., Chrzanowska P., 2013. Bezpośrednie inwestycje zagraniczne w polskich miastach. Economics and Management, vol. 3, Białystok: Politechnika Białostocka.

Gonda-Soroczyńska E., Przybyła K., 2013. Transformation of Wrocław economic base. Research Papers of Wrocław University of Economics, vol. 320, Wroclaw: Wrocław University of Economics.

Kunzmann K., Wegener M., 1991. The pattern of urbanisation in Western Europe, vol. 350/351, pp. 282-291.

Muller B., Finka M., Lintz G. (eds.), 2005. Rise and decline of industry in Central and Eastern Europe. A comparative study of cities and regions in eleven countries. Heidelberg: Springer. 
Rachwał T., 2010. Struktura przestrzenna i działowa przemysłu Polski na tle Unii Europejskiej $w$ dwudziestolecie rozpoczęcia procesów transformacji systemowej, Prace Komisji Geografii Przemysłu. Warsaw-Cracow: KGP.

Siłka P., 2012. Typologia miast ze względu na potencjał innowacyjny. Prace Komisji Geografii Przemysłu. Warsaw-Cracow: KGP.

Strategy of the Lower Silesia Province, 2013.

Study of Directions and Conditions of Spatial Development of Wroclaw, 2010.

Zajdel M., 2010. Trójsektorowa struktura zatrudnienia w polskiej gospodarce jako miernik rozwoju (wybrane aspekty) [in:] Nierówności społeczne a wzrost gospodarczy, Zeszyt Nr 16. Rzeszów: Uniwersytet Rzeszowski.

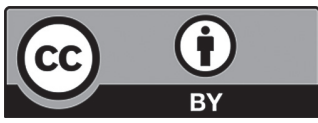


http://rcin.org.pl 